\title{
TESTIMONIE VERSUS DEFAMATION : EDUKASI BATASAN PENCEMARAN NAMA BAIK DAN PENDAPAT KONSUMEN DALAM MARKETPLACE
}

\author{
Putri Purbasari Raharningtyas Marditia ${ }^{1}$, Yasyfa Silmianra Hafizha ${ }^{2}$ \\ ${ }^{1}$ Fakultas Hukum, Universitas Atmajaya Jakarta \\ Surel :putri.purbasari@atmajaya.ac.id \\ ${ }^{2}$ Mahsiswa Fakultas Hukum, Universitas Katolik Indonesia Atma Jaya \\ surel : silmianraa@yahoo.com
}

\begin{abstract}
Marketplace connects sellers and buyers in conducting online buying and selling activities. One of the factors that influence consumers to buy an item from a seller is the assessment given by previous buyers in the form of ratings (in the form of stars with a rating scale of 1 to 5) and reviews. Criticisms written by previous buyers are often a consideration for potential buyers to buy the item from the seller, especially if the criticism relates to the quality of the product and the suitability of the product with the description written by the author. In addition, the reputation of the seller is also a consideration for potential buyers in buying an item from the seller. Nevertheless, the buyer as a consumer has the right to write an honest review in accordance with his experience of buying goods from the seller. However, it will be a problem if the rights of the buyer or consumer in the provisions of Article 4 letter $d$ of the Consumer Protection Act are used without being accompanied by their obligations as a buyer or are used excessively to violate the seller's right to have a good reputation. So it is necessary to educate the public regarding this phenomenon. Methods of implementing community service activities by conducting workshops through the Youtube Platform. So that through this Educational Video uploaded on YouTube media, at least it can educate the public to become smart people in media, namely: one's ability to access, analyze, evaluate, and communicate information in various forms of media and one's ability to think critically in accepting a information.
\end{abstract}

Keywords: Testimonies, defamation, education, defamation, marketplace

\section{ABSTRAK}

Marketplace menghubungkan penjual dan pembeli dalam melakukan kegiatan jual beli secara online. Salah satu faktor yang mempengaruhi konsumen untuk membeli suatu barang dari penjual adalah penilaian yang diberikan oleh para pembeli sebelumnya yang berupa ratings (yang berupa bintang dengan skala penilaian 1 sampai 5) dan ulasan. Kritik yang dituliskan oleh para pembeli sebelumnya seringkali menjadi pertimbangan bagi calon pembeli untuk membeli barang tersebut dari penjual, terutama apabila kritik tersebut berkaitan dengan kualitas produk dan kesesuaian produk dengan deskripsi yang dituliskan penulis. Selain itu, reputasi penjual juga menjadi pertimbangan calon pembeli dalam membeli suatu barang dari penjual tersebut. Meskipun demikian, pembeli selaku konsumen berhak untuk menuliskan ulasan jujur sesuai dengan pengalamannya membeli barang dari penjual. Namun akan menjadi masalah apabila hak pembeli atau konsumen dalam ketentuan Pasal 4 huruf d Undang-Undang Perlindungan Konsumen tersebut digunakan tanpa disertai dengan kewjibannya sebagai pembeli atau digunakan secara berlebihan hingga melanggar hak penjual untuk memiliki reputasi yang baik. Sehingga perlu dilakukan Edukasi masyarakat terkait fenomena tersebut Metode pelaksanakan kegiatan pengabdian kepada masyarakat dengan melakukan Workshop melalui Platform Youtube. Sehingga melalui Video Edukasi yang diunggah dalam media yotube ini setidaknya dapat mengedukasi masyarakat untuk menjadi orang-orang yang cerdas dalam bermedia adalah : kemampuan seseorang untuk mengakses, menganalisis, mengevaluasi, dan mengkomunikasikan informasi dalam berbagai bentuk media dan Kemampuan seseorang untuk berpikir kritis dalam menerima sebuah informasi.

Kata Kunci: Testimonie, defamation, edukasi , pencemaran nama baik, marketplace

\section{PENDAHULUAN}

Di era digital ini, internet sangat mempermudah manusia untuk melakukan segala kegiatan dengan manusia lain tanpa dibatasi waktu dan jarak, salah satunya adalah kegiatan transaksi jual beli secara online. Pihak perantara yang memfasilitasi penjual dan pembeli dalam melakukan transaksi jual beli secara online disebut sebagai marketplace. Marketplace merupakan suatu 
platform yang bertugas sebagai perantara antara penjual dan pembeli dalam melakukan proses transaksi jual beli secara online dengan menyediakan berbagai fasilitas seperti pemilihan produk seusai kategori, fitur chat antara penjual dengan pembeli, estimasi pengiriman, metode pembayaran, dan lain-lain. ${ }^{1}$ Marketplace terbagi menjadi tiga aspek, yaitu business to business (B2B), business to customer (B2C), dan customer to customer (C2C). ${ }^{2}$ Di Indonesia, marketplace yang paling lazim dijumpai dalam kehidupan sehari-hari adalah marketplace dengan aspek business to customer (B2C).

Marketplace menghubungkan penjual dan pembeli dalam melakukan kegiatan jual beli secara online. Salah satu faktor yang mempengaruhi konsumen untuk membeli suatu barang dari penjual adalah penilaian yang diberikan oleh para pembeli sebelumnya yang berupa ratings (yang berupa bintang dengan skala penilaian 1 sampai 5) dan ulasan. Kritik yang dituliskan oleh para pembeli sebelumnya seringkali menjadi pertimbangan bagi calon pembeli untuk membeli barang tersebut dari penjual, terutama apabila kritik tersebut berkaitan dengan kualitas produk dan kesesuaian produk dengan deskripsi yang dituliskan penulis. Selain itu, reputasi penjual juga menjadi pertimbangan calon pembeli dalam membeli suatu barang dari penjual tersebut. Reputasi penjual dapat dilihat pada profil penjual dalam marketplace yang berupa rata-rata ulasan dengan skala penilaian 1-5. Hal tersebut membuktikan bahwa ulasan dari konsumen sangat berpengaruh terhadap reputasi penjual, semakin banyak ratings dan ulasan positif dari pembeli, maka semakin meningkat pula reputasi penjual. Namun 1 ulasan buruk dengan rating 1 bintang dapat menurunkan nilai rating produk dan apabila hal tersebut terjadi beberapa kali di produk yang berbeda yang dijual oleh penjual yang sama, maka akan mempengaruhi nilai reputasi penjual.

Meskipun demikian, pembeli selaku konsumen berhak untuk menuliskan ulasan jujur sesuai dengan pengalamannya membeli barang dari penjual. Dalam Pasal 4 huruf d Undang-Undang Nomor 8 Tahun 1999 tentang Perlindungan Konsumen disebutkan bahwa konsumen berhak untuk didengar pendapat dan keluhannya atas barang dan atau jasa yang digunakan. Hak yang timbul dalam undang-undang tersebut tentunya disertai dengan kewajiban pembeli atau konsumen dalam membeli suatu barang. Adapun kewajiban bagi konsumen yang menyertai hak tersebut diatur dalam Pasal 5 huruf a Undang-Undang Perlindungan Konsumen, dimana konsumen wajib untuk membaca atau mengikuti petunjuk informasi dan prosedur pemakaian atau pemanfaatan barang dan atau jasa demi keamanan dan keselamatan. Dalam membeli suatu barang melalui marketplace, penulis wajib untuk membaca deskripsi produk yang dituliskan oleh penjual sebelum membeli barang tersebut. Apabila terdapat informasi yang kurang dalam kolom deskripsi produk, penulis bisa menanyakannya kepada penjual.

Kewajiban tersebut timbul sebagai tindakan preventif dari hal-hal yang tidak diingingkan seperti barang yang dibeli tidak sesuai dengan yang diharapkan pembeli atau waktu pengiriman yang relatif lama (terutama jika barang yang akan dibeli berstatus preorder). Dan jika penjual tidak memberikan pelayanan yang baik, seperti misalnya penjual membalas pertanyaan dengan katakata yang kurang sopan atau membalasnya dalam jangka waktu yang lama hingga berhari-hari, maka pembeli juga dapat memutuskan untuk tidak membeli barang yang diinginkan melalui penjual tersebut. Namun akan menjadi masalah apabila hak pembeli atau konsumen dalam ketentuan Pasal 4 huruf d Undang-Undang Perlindungan Konsumen tersebut digunakan tanpa disertai dengan kewjibannya sebagai pembeli atau digunakan secara berlebihan hingga melanggar hak penjual untuk memiliki reputasi yang baik dengan memberikan ulasan buruk

\footnotetext{
${ }^{1}$ Muhammad Robith Adani, "Kenali Apa itu Marketplace beserta Jenis dan Contoh Penerapannya", https://www.sekawanmedia.co.id/pengertian-marketplace/, ditelusuri 28 Mei 2021.

2 Andy, "Lebih Untung Mana, Jualan di Marketplace atau di Toko Online Sendiri?", https://bikin.website/blog/marketplace-vs-toko-online/, ditelusuri 29 Mei 2021.
} 
yang berpotensi mencemari nama baik penjual dalam marketplace. Jika hal itu terjadi, maka sesuai dengan ketentuan Pasal 6 huruf b Undang-Undang Perlindungan Konsumen, penjual berhak untuk menuntut pembeli atas ulasan buruk yang diberikan oleh dirinya yang dapat berpotensi mencemari nama baik penjual hingga merusak reputasi penjual. Pasal 6 huruf $b$ Undang-Undang Perlindungan Konsumen berbunyi: "Pelaku usaha berhak untuk mendapat perlindungan hukum dari tindakan konsumen yang beritikad tidak baik".

Pencemaran nama baik dikenal juga dengan istilah penghinaan, yang pada dasarnya adalah menyerang kehormatan dan nama baik seseorang yang bukan dalam arti seksual sehingga orang itu merasa dirugikan. ${ }^{3}$ Ulasan buruk yang dituliskan oleh pembeli-pembeli sebelumnya akan membuat calon pembeli mempertimbangkan atau meragukan untuk membeli barang yang diinginkannya dari penjual tersebut. Hal ini dapat menimbulkan kerugian bagi penjual karena ulasan-ulasan buruk tersebut menyebabkan calon pembeli lainnya tidak jadi membeli barang dari penjual tersebut dan dapat mengakibatkan terjadinya penurunan omset. Jika hal itu terjadi, maka sesuai dengan ketentuan Pasal 1372 Kitab Undang-Undang Hukum Perdata, penjual berhak untuk mengajukan ganti rugi kepada pembeli yang menuliskan ulasan buruk atas pemulihan reputasi yang tercemar. Pasal 1372 KUHPerdata berbunyi:

"Tuntutan perdata tentang hal penghinaan diajukan untuk memperoleh penggantian kerugian serta pemulihan kehormatan dan nama baik. Dalam menilai satu sama lain, hakim harus memperhatikan kasar atau tidaknya penghinaan, begitu pula pangkat, kedudukan, dan kemampuan kedua belah pihak, dan keadaan."

Di Indonesia, ketentuan tentang larangan pencemaran nama baik secara digital telah diatur di dalam Undang-Undang Nomor 11 Tahun 2008 tentang Informasi dan Transaksi Elektronik (UU ITE). Pasal 27 ayat (3) Undang-Undang Informasi dan Transaksi Elektronik melarang siapapun dengan sengaja dan tanpa hak mendistribusikan dan atau mentransmisikan dan atau membuat dapat diaksesnya informasi elektronik dan atau dokumen elektronik yang memiliki muatan penghinaan atau pencemaran nama baik. Pasal 28 ayat (2) Undang-Undang Informasi dan Transaksi Elektronik melarang siapapun dengan sengaja dan tanpa hak menyebarkan informasi yang ditujukan untuk menimbulkan rasa kebencian atau permusuhan individu dan/atau kelompok masyarakat tertentu berdasarkan atas suku, agama, ras, dan antargolongan (SARA).

Berdasr hal tersebutlah perlu mekanisme mencari akar permasalahan mengapa dan bagaimana edukasi yang dilakukan, untuk pembeli menuliskan ulasan buruk tanpa menyerang kehormatan atau nama baik berupa reputasi penjual apabila pembeli mengalami kendala atas barang yang diterimanya dan atau mendapatkan pelayanan yang buruk dari penjual pada marketplace.

\section{METODE PELAKSANAAN PKM}

Metode yang digunakan dalam melaksanakan kegiatan pengabdian kepada masyarakat dengan melakukan Workshop melalui Platform Youtube. Workshop adalah kegiatan atau acara yang dilakukan oleh beberapa orang, yang mempunyai keahlian di suatu bidang tertentu. Yang tujuannya adalah untuk membahas suatu masalah dan mengajari beberapa peserta workshop tersebut. pendek kata workshop adalah gabungan antara teori dan juga praktek, dalam suatu kegiatan.Sedangnkan Youtube merupakan salah satu bentuk media sosial berbasis video. Beragam konten video bisa diakses dalam Youtube, mulai dari Musik, Film, Berita dan Informasi, Olahraga, Gaya hidup, Gaming, dan Vlog.

\footnotetext{
${ }^{3}$ Ernest Sengi, Kebijakan Formulasi Tindak Pidana Pencemaran Nama Baik Melalui Media Sosial, Semarang: CV. Pilar Nusantara, 2018, hlm. 16.
} 
Seminar Nasional Hasil Penelitian dan Pengabdian Kepada Masyarakat 2021

Pengembangan Ekonomi Bangsa Melalui Inovasi Digital Hasil Penelitian dan

Pengabdian Kepada Masyarakat

Jakarta, 21 Oktober 2021

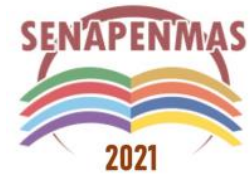

\section{HASIL SURVEY}

Pengabdian masyarakat ini dilaksanakan dengan menggunakan kanal youtube melalui link : https://www.youtube.com/watch? $\mathrm{v}=\mathrm{p}$ YbRe_iHrEA. Melalui video ini Penulis juga membagikan Kuisoner melalui Google Form (https://bit.ly/SURVEYMARKETPLACE), ${ }^{4}$ Adapun tujuan dari diadakannya kuesioner ini adalah untuk mencari tahu seberapa besar pengaruh dan dampak ulasan buruk terhadap reputasi penjual yang dapat dilihat pada profil nya dalam marketplace (dengan skala 0-5) yang dapat mempengaruhi keputusan konsumen untuk membeli barang melalui penjual dalam marketplace. Adapun kriteria responden yang ditargetkan adalah sebagai berikut: (1) Berusia minimal 18 tahun; (2) Memiliki pengalaman berbelanja melalui marketplace; (3) Memiliki pengalaman melihat ulasan buruk di marketplace; dan (4) Memiliki pengalaman menuliskan ulasan buruk di marketplace. Berikut adalah pemaparan data secara singkat dari 100 responden target penelitian yang telah menjawab pertanyaan-pertanyaan pada Google Forms:
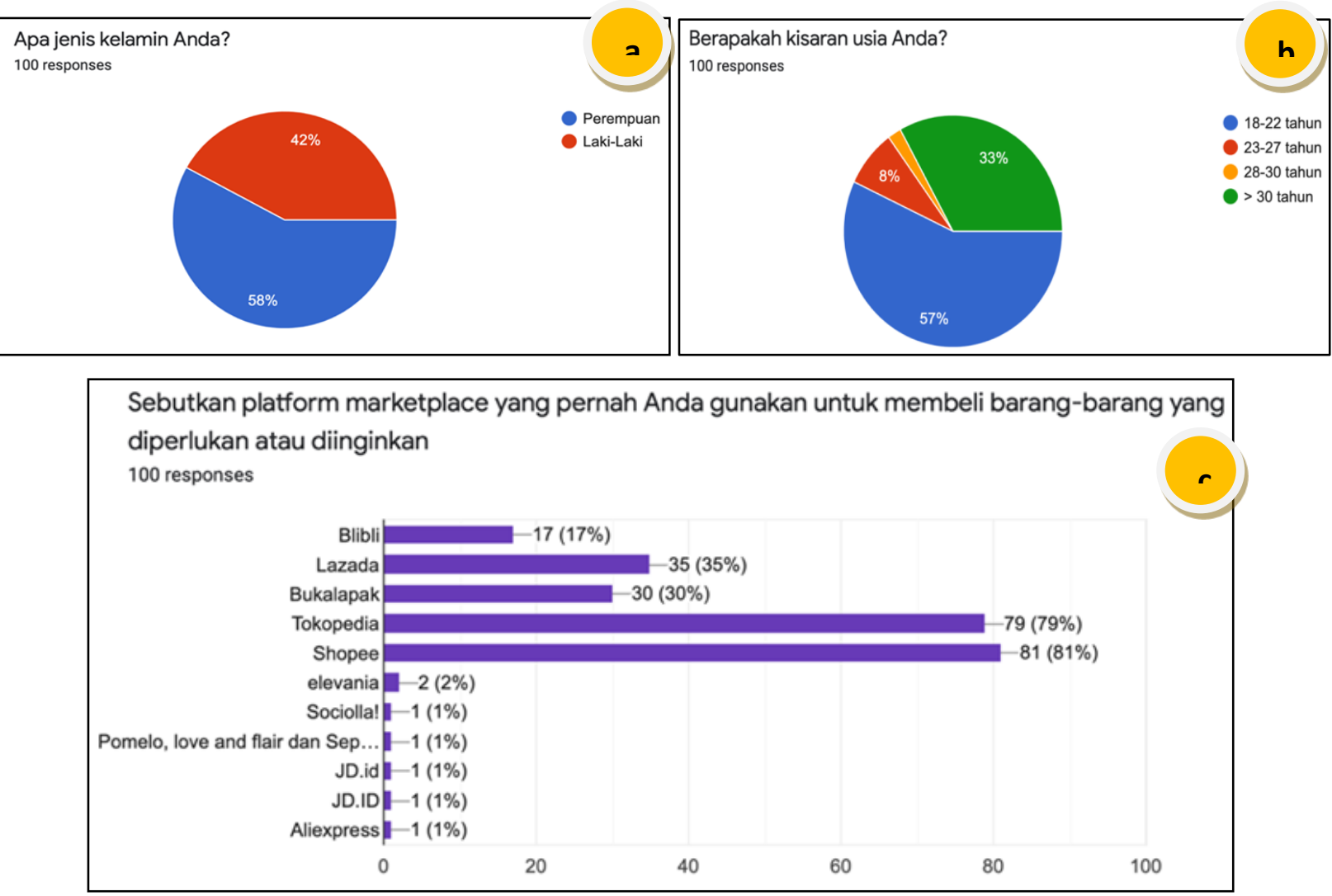

Jika barang yang dibeli melalui marketplace ternyata tidak sesuai dengan ekspektasi Anda, apakah

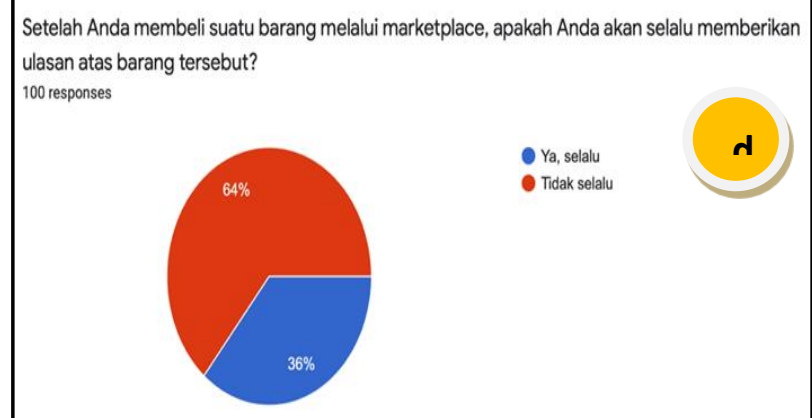
Anda akan langsung mengungkapkan kekecewaan Anda melalui ulasan atas barang tersebut? 100 responses

ulasan atas barang tersebut? ${ }^{4}$ Asti Musman, Kaizen For Life: Kunci Sukses Continous Improvement di Era 4.0, Yogyakarta: Anak Hebat
Indonesia, 2019, hlm 137. 

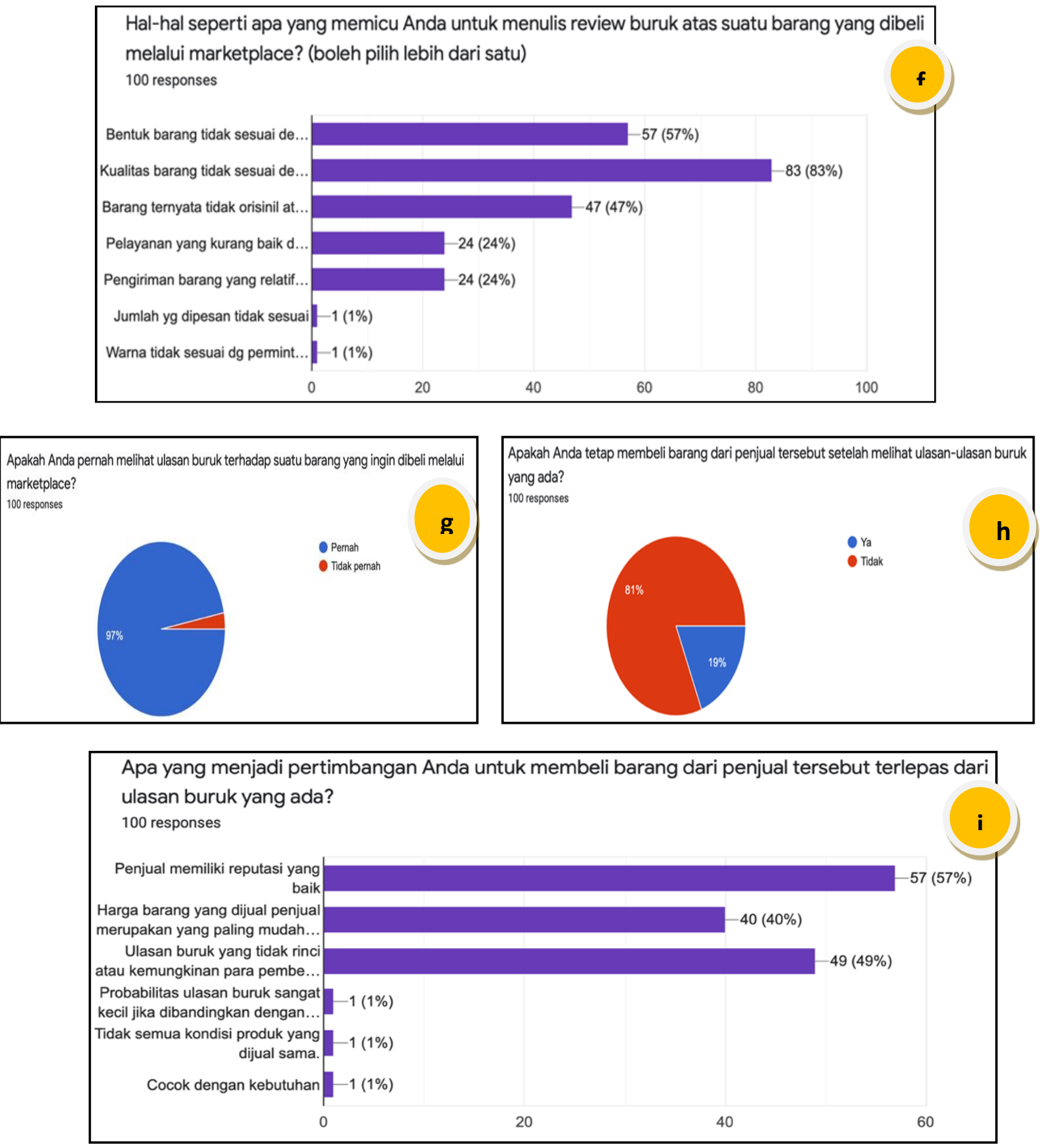

Keterangan dari diagram diatas adalah :

a. Diagram tersebut menunjukkan bahwa sebanyak $58 \%$ responden berjenis kelamin perempuan dan sebanyak $42 \%$ responden berjenis kelamin laki-laki.

b. Diagram tersebut menunjukkan bahwa sebanyak 57\% responden berusia antara 18 hingga 22 tahun, 33\% responden berusia lebih dari 30 tahun, $8 \%$ responden berusia 23 hingga 37 tahun, dan $2 \%$ responden berusia 28 hingga 30 tahun.

c. Diagram tersebut menunjukkan Penggunaan Platform untuk berbelanja : Shopee $81 \%$ responden; Tokopedia $79 \%$ responden ; Lazada 35\% responden; Bukalapak $30 \%$ responden; Blibli 17\%, responden; Elevenia 2\% responden; Sociolla, JD.id, Aliexpress, Pomelo, Love and Flair, dan Sephora masing-masing $1 \%$ responden.

d. Diagram tersebut menunjukkan bahwa sebanyak $64 \%$ responden tidak selalu memberikan ulasan setelah berbelanja melalui marketplace dan sebanyak $36 \%$ responden selalu memberikan ulasan setelah berbelanja melalui marketplace. 
e. Diagram tersebut menunjukkan bahwa sebanyak $73 \%$ responden akan langsung mengungkapkan kekecewaan berupa ulasan buruk terhadap barang yang dibelinya melalui marketplace dan $27 \%$ responden tidak akan langsung mengungkapkan kekecewaan berupa ulasan buruk terhadap barang yang dibelinya melalui marketplace.

f. Diagram tersebut menunjukkan bahwa Alasan untuk menuliskan ulasan buruk atas barang yang telah dibeli karena : (1) kualitas barang tidak sesuai sebanyak $83 \%$ responden ; (2) wujud barang tidak sesuai dengan yang ada di foto sebanyak $57 \%$ responden ; (3) barang yang diterima ternyata tidak orisinil $47 \%$ responden ; (4) pelayanan yang kurang baik dari penjual $24 \%$ responden ; (5) pengiriman barang relatif lebih lama $24 \%$ responden ;

g. Diagram tersebut menunjukkan bahwa sebanyak $97 \%$ responden pernah melihat ulasan buruk terhadap suatu barang yang ingin dibeli melalui marketplace, dan 3\% responden;

h. Diagram tersebut menunjukkan bahwa sebanyak $81 \%$ responden memutuskan untuk tidak membeli barang dari penjual tersebut setelah melihat ulasan-ulasan buruk yang ada.

i. Diagram tersebut menunjukkan hal-hal yang menjadi responden untuk tetap membeli barang dari penjual tersebut terlepas dari ulasan buruk yang ada. Sebanyak 57\% responden mempertimbangkan penjual yang memiliki reputasi baik (bisa dilihat dari rating keseluruhan atas produk-produk yang dijual), $49 \%$ responden memiliki mempertimbangkan ulasan buruk yang tidak rinci atau kemungkinan para pembeli ulasan tidak membaca kolom deskripsi sebelum membeli barang (kesalahan dari pembeli sebelumnya), $40 \%$ responden mempertimbangkan harga barang yang dijual penjual merupakan yang paling mudah dibandingkan dengan harga barang dari penjual lain, $1 \%$ responden mempertimbangkan untuk tetap membeli barang tersebut karena tidak semua kondisi produk yang dijual sama, dan $1 \%$ responden lainnya mempertimbangkan untuk tetap membeli barang tersebut karena cocok dengan kebutuhan.

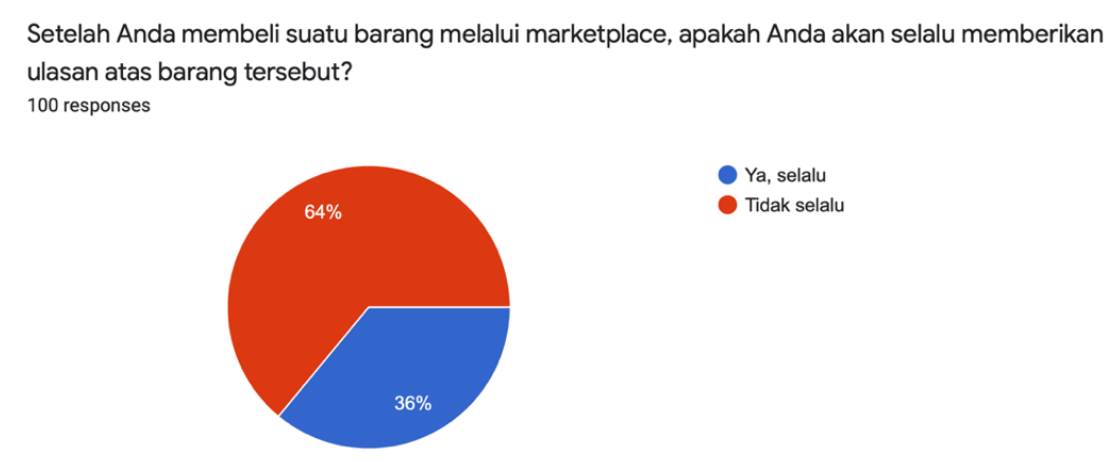

\section{ANALISA DAN PEMBAHASAN}

Dalam rangka meningkatkan harkat dan martabat pembeli sebagai konsumen, pembeli perlu meningkatkan kesadaran, pengetahuan, kepedulian, kemampuan dan kemandirian untuk melindungi dirinya sendiri dari hal- hal yang tidak diinginkan ketika melakukan transaksi jual beli, khususnya dalam marketplace. Adapun Undang-Undang Nomor 8 Tahun 1999 tentang Perlindungan Konsumen diciptakan sebagai landasan hukum bagi pemerintah dan lembaga perlindungan konsumen swadaya masyarakat untuk mewujudkan keseimbangan perlindungan kepentingan konsumen dan pelaku usaha agar terciptanya perekonomian Indonesia yang sehat. ${ }^{5}$ Sebagaimana diatur dalam Pasal 4 Undang-Undang Perlindungan Konsumen, hak-hak konsumen

${ }^{5}$ Undang-Undang Nomor 8 Tahun 1999 tentang Perlindungan Konsumen, TLN Nomor 3821. 
salah satunya adalah Hak untuk didengar pendapat dan keluhannya atas barang dan/atau jasa yang digunakan.

Disebutkan dalam huruf d bahwa pembeli sebagai konsumen berhak untuk mengajukan keluhan atas barang yang dibeli, dan keluhan tersebut berhak untuk didengar oleh penjual sebagai pelaku usaha. Meski demikian, Oemar Seno Adji dalam bukunya yang berjudul "Mass Media dan Hukum" menyatakan bahwa kritik diperbolehkan dan bahkan diperlukan, namun kritik yang dituangkan harus bersifat konstruktif. . $^{6}$ Adapun yang dimaksud dengan kritik konstruktif adalah saran yang diberikan secara spesifik disertai dengan solusi yang dapat ditindaklanjuti. ${ }^{7}$ Oemar juga menambahkan, kritik yang dituai tidak boleh bersifat formale beledging (penghinaan formil), yaitu suatu penghinaan yang mengemukakan bentuk atau cara mengemukakan pernyataan tersebut. ${ }^{8}$

Rendahnya literasi media dalam masyarakat digital menjadi salah satu pemicu maraknya dampak negatif penggunaan internet yang salah satunya adalah penyebaran konten yang memuat penghinaan atau pencemaran nama baik. Adapun yang dimaksud dengan cerdas bermedia adalah memiliki kemampuan untuk menguasai dan menggunakan sosial media secara bijak sesuai dengan fungsi yang diharapkan, seperti saling membagikan informasi yang bermanfaat. ${ }^{9}$ Namun tidak dapat dipungkiri bahwa kecerdasan masyarakat sebagai pengguna internet sangat diperlukan dalam mengolah dan menelaah informasi yang ada, termasuk ulasan-ulasan terhadap suatu produk dalam marketplace dengan memastikan kebenaran informasi tersebut sebelum membeli barang tersebut dan kemudian menyesal karena tidak menelaah deskripsi produk dengan benar. Kecermatan pembeli dalam menelaah informasi sebelum membeli suatu produk dalam marketplace dapat menghindari penulisan ulasan buruk yang apabila ulasan tersebut tidak dituliskan secara baik, maka kemungkinan akan menimbulkan permasalahan dengan penjual.

Sehingga melalui Video Edukasi yang diunggah dalam media yotube ini setidaknya dapat mengedukasi masyarakat untuk menjadi orang-orang yang cerdas dalam bermedia, yang sbb $:^{10}$

a. kemampuan seseorang untuk mengakses, menganalisis, mengevaluasi, dan mengkomunikasikan informasi dalam berbagai bentuk media. ${ }^{11}$ Adanya rasa tanggung jawab yang muncul dalam masyarakat membuat mereka semakin berhati-hati untuk tidak menuliskan sesuatu yang bertentangan dengan hukum, etika, dan norma.

b. Kemampuan seseorang untuk berpikir kritis dalam menerima sebuah informasi sangat dibutuhkan agar tidak terjerumus pada informasi-informasi yang tidak bisa dipertanggungjawabkan kebenarannya. ${ }^{12}$ Ketelitian dan sikap kritis atas kebenaran suatu informasi hanya dimungkinkan oleh orang-orang terdidik dan menguasai budaya membaca, serta memahami cara menguji kebenaran akan suatu informasi. ${ }^{13}$

\footnotetext{
${ }^{6}$ Rosa Agustina, op.cit., hlm 192.

${ }^{7}$ Indeed Editorial Team, "Understanding Constructive Criticism: Definition, Tips, and Examples" https://www.indeed.com/career-advice/career-development/constructive-criticism, ditelusuri 14 Juli 2021.

${ }^{8}$ Rosa Agustina, loc.cit.

${ }^{9}$ Rosmidah et.al., "Sosialisasi Literasi Cerdas Bermedia Sosial Pada Pelajar SMP Negeri Kota Sungai Penuh", Prosiding Seminar Hukum dan Publikasi Nasional (Serumpun) II "Transformasi Cita Hukum Mewujudkan Indonesia Maju, 2020, hlm 312.

${ }^{10}$ Naila dkk., "Langkah Cerdas Bermedia Sosial Di Kalangan Santri Milenial”, Jurnal Sains dan Teknologi, Vol 11, No. 2, 2019, 42.

${ }^{11}$ Diskominfo, "Pengertian Literasi Media”, https://diskominfo.badungkab.go.id/artikel/17916-pengertian-literasimedia, ditelusuri 15 Juli 2021.

${ }^{12}$ Aldino Bagus Prasetyo, "Strategi Berpikir Kritis dalam Penggunaan Media Sosial Di Kalangan Jamaah Masjid Gunungsari Indah Surabaya”, Jurnal Ilmu Informasi dan Perpustakaan, http://repository.unair.ac.id/74757/3/JURNAL_Fis.IIP.37\%2018\%20Pra\%20s.pdf, hlm 3.

${ }^{13}$ Sahrul Mauludi, op.cit., hlm 361.
} 
Selain menjadi cerdas dalam bermedia, penjual dan pembeli dalam marketplace sebagai masyarakat digital juga harus memperhatikan etika dalam melakukan komunikasi menggunakan media sosial. Dalam menggunakan media sosial, seseorang haruslah memiliki kesopanan dan kebijakan terhadap tulisan atau pernyataan yang akan dipublikasikan olehnya.

\section{KESIMPULAN}

Kritik yang dituliskan oleh para pembeli sebelumnya seringkali menjadi pertimbangan bagi calon pembeli untuk membeli barang tersebut dari penjual, terutama apabila kritik tersebut berkaitan dengan kualitas produk dan kesesuaian produk dengan deskripsi yang dituliskan penulis. Selain itu, reputasi penjual juga menjadi pertimbangan calon pembeli dalam membeli suatu barang dari penjual tersebut. Meskipun demikian, pembeli selaku konsumen berhak untuk menuliskan ulasan jujur sesuai dengan pengalamannya membeli barang dari penjual. Namun akan menjadi masalah apabila hak pembeli atau konsumen dalam ketentuan Pasal 4 huruf $\mathrm{d}$ Undang-Undang Perlindungan Konsumen tersebut digunakan tanpa disertai dengan kewjibannya sebagai pembeli atau digunakan secara berlebihan hingga melanggar hak penjual untuk memiliki reputasi yang baik. Sehingga perlu dilakukan Edukasi masyarakat terkait fenomena tersebut Metode pelaksanakan kegiatan pengabdian kepada masyarakat dengan melakukan Workshop melalui Platform Youtube. Sehingga melalui Video Edukasi yang diunggah dalam media yotube ini setidaknya dapat mengedukasi masyarakat untuk menjadi orang-orang yang cerdas dalam bermedia adalah : kemampuan seseorang untuk mengakses, menganalisis, mengevaluasi, dan mengkomunikasikan informasi dalam berbagai bentuk media dan Kemampuan seseorang untuk berpikir kritis dalam menerima sebuah informasi.

\section{REFERENSI}

Aldino Bagus Prasetyo, "Strategi Berpikir Kritis dalam Penggunaan Media Sosial Di Kalangan Jamaah Masjid Gunungsari Indah Surabaya", Jurnal Ilmu Informasi dan Perpustakaan, http://repository.unair.ac.id/74757/3/JURNAL_Fis.IIP.37\%2018\%20Pra\%20s.pdf, hlm 3.

Andy, "Lebih Untung Mana, Jualan di Marketplace atau di Toko Online Sendiri?", https://bikin.website/blog/marketplace-vs-toko-online/, ditelusuri 29 Mei 2021.

Asti Musman, Kaizen For Life: Kunci Sukses Continous Improvement di Era 4.0, Yogyakarta: Anak Hebat Indonesia, 2019, hlm 137.

Diskominfo, "Pengertian Literasi Media", https://diskominfo.badungkab.go.id/artikel/17916pengertian-literasi-media, ditelusuri 15 Juli 2021.

Ernest Sengi, Kebijakan Formulasi Tindak Pidana Pencemaran Nama Baik Melalui Media Sosial, Semarang: CV. Pilar Nusantara, 2018, hlm. 16.

Indeed Editorial Team, "Understanding Constructive Criticism: Definition, Tips, and Examples" https://www.indeed.com/career-advice/career-development/constructive-criticism, ditelusuri 14 Juli 2021.

Muhammad Robith Adani, "Kenali Apa itu Marketplace beserta Jenis dan Contoh Penerapannya", https://www.sekawanmedia.co.id/pengertian-marketplace/, ditelusuri 28 Mei 2021.

Naila dkk., "Langkah Cerdas Bermedia Sosial Di Kalangan Santri Milenial", Jurnal Sains dan Teknologi, Vol 11, No. 2, 2019, 42.

Rosmidah et.al., "Sosialisasi Literasi Cerdas Bermedia Sosial Pada Pelajar SMP Negeri Kota Sungai Penuh", Prosiding Seminar Hukum dan Publikasi Nasional (Serumpun) II "Transformasi Cita Hukum Mewujudkan Indonesia Maju, 2020, hlm 312.

Undang-Undang Nomor 8 Tahun 1999 tentang Perlindungan Konsumen, TLN Nomor 3821. 